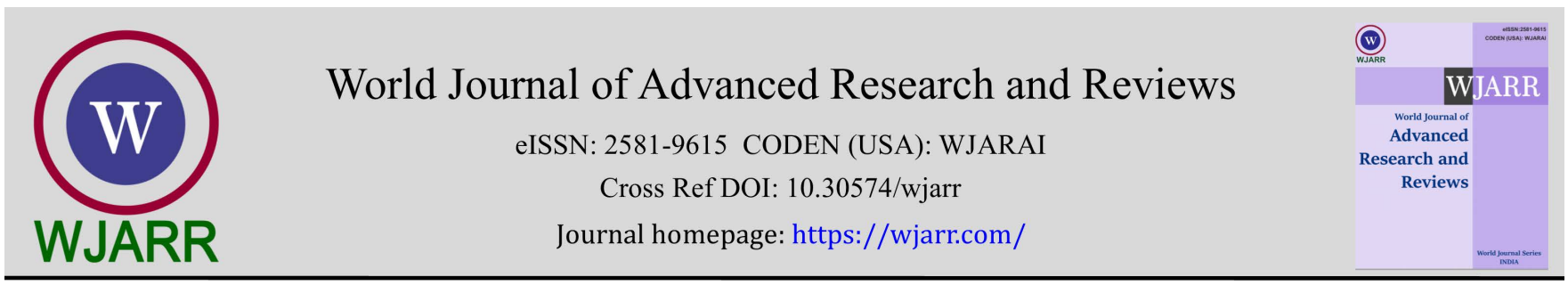

(RESEARCH ARTiClE)

\title{
Antibacterial activity of the bacteriocins producing- lactic acid bacteria isolated from some processed meat products against selected indicator bacterial strains
}

\author{
Huda M Selman ${ }^{1}$, Ahmed A Mahdi 2, Nagat A El Rofaei ${ }^{3}$ and Elnasri M Mutwali 4,* \\ ${ }^{1}$ Department of Biology, Faculty of Education, Alzaiem Alazhari University, Khartoum, Sudan. \\ 2 Department of agricultural Biotechnology, Faculty of Agriculture, University of Khartoum, Sudan. \\ ${ }^{3}$ Biotechnology Department, Faculty of Science and Technology, Omdurman Islamic University, Omdurman, Sudan. \\ ${ }^{4}$ Department of Biology, Faculty of Education, Alzaiem Alazhari University, Khartoum, Sudan.
}

World Journal of Advanced Research and Reviews, 2021, 12(02), 640-645

Publication history: Received on 19 October 2021; revised on 28 November 2021; accepted on 30 November 2021

Article DOI: https://doi.org/10.30574/wjarr.2021.12.2.0643

\begin{abstract}
In this study, a total of 25 Lactic Acid Bacteria (LAB) isolates from 15 samples [4 burgers, 4 frankfurters, 3 pastramis, 2 sausages and 2baby faeces] were screened for their ability to produce inhibitory substances against three microorganisms which were isolated from meat products: (Salmonella typhi, Staphylococcus aureus and Escherichia coli). Other indicators (reference target organisms) were obtained from the Central Public Health Laboratory, Khartoum State, Sudan. These were: Salmonella typhi ATCC14023, Staphylococcus aureus ATCC29213 and Escherichia coli ATCC25922. The antagonistic activities of the isolates were screened by the direct spot-on-lawn method and welldiffusion method. A total of 25 isolates of LAB were obtained, 15 of which produced promising inhibition zones against all or some of the indicator bacterial strains.
\end{abstract}

Keywords: Antibacterial activity; Indicator bacterial strains; Inhibitory substances; Khartoum State; Sudan

\section{Introduction}

Meat and meat products are the main food sources in daily diets of people in developing countries that affected by several factors. Meat products diversity and their ease to use and do not require for cooking of them increased their using, especially in young people [1, 2]. Lactic Acid Bacteria (LAB) are characterized as Gram-positive cocci or rods, nonaerobic but aerotolerant, able to ferment carbohydrates for energy and lactic acid production. The metabolic pathway from glucose may be homofermentative or heterofermentative. Lactic acid bacteria are also able to produce small organic substances that contribute with aroma and give specific organoleptic attributes to the products [3]. Lactic acid bacteria include various major genera: Lactobacillus, Lactococcus, Carnobacterium, Enterococcus, Lactosphaera, Leuconostoc, Melissococcus, Oenococcus, Pediococcus, Streptococcus, Tetragenococcus, Vagococcus and Weissella. Other genera are: Aerococcus, Microbacterium, Propionibacterium and Bifidobacterium [4]. LAB can exert a bioprotective or inhibitory effect against other microorganisms as a result of the competition for nutrients and/or of the production of bacteriocins or other antagonistic compounds such as organic acids, hydrogen peroxide and enzymes. Food processors face a major challenge with consumers demanding safe foods with a long shelf life, but also expressing their preference for minimally processed products, less severely damaged by heat and freezing and not containing chemical preservatives. LAB antimicrobial activity is due to the production of organic acids (in particular, lactic acid and acetic acid), carbon dioxide, hydrogen peroxide and diacetyl [5]. Also some of these bacteria produce antagonistic substances, called bacteriocins, which in small amounts are very active against pathogens [ 6,7 ] .The incorporation of these compounds as biopreservative ingredients into model food has been shown to be effective in the control of pathogenic

\footnotetext{
* Corresponding author: Elnasri M Mutwali

Department of Biology, Faculty of Education, Alzaiem Alazhari University, Khartoum, Sudan.

Copyright $(2021$ Author(s) retain the copyright of this article. This article is published under the terms of the Creative Commons Attribution Liscense 4.0.
} 
and spoilage micro-organisms [ 8 ] .The aim of this study was to evaluate the antibacterial activity of the bacteriocins producing lactic acid bacteria isolated from some processed meat products against selected indicator bacterial strains.

\section{Material and methods}

14 samples of frozen meat products in plastic packaged ( 4 frankfurter, 4 burger, 3 pastrami and 2 sausages) from four different meat processing factories in Khartoum State, Sudan were collected from Elmohandsein markets. They were obtained in sterile insulated iced containers and immediately transported to the laboratory. And baby faces sample obtained from house-healthy new born infant age 17 days.

\subsection{Isolation of bacteriocin producing $L A B$}

In this study, a total of $25 \mathrm{LAB}$ isolated from 14 samples mentioned previously, were screened for their ability to produce inhibitory substances against three microorganisms, which were isolated from meat products and identified according to Bergey's Manual [ 9, 10,11,12 ] as: Salmonella typhi, Staphylococcus aureus and Escherichia coli. Other indicators (reference target organisms) were obtained from the Central Public Health Laboratory, Khartoum State, Sudan. They were: Staphylococcus aureus ATCC29213, Salmonella typhi ATCC14023, Escherichia coli ATCC25922.

\subsection{Susceptibility testing}

The antagonistic activities of the isolates were initially screened by the direct spot-on-lawn method [13], which were afterwards confirmed by the well diffusion method [14].

\subsection{Screening by the spot-on-lawn method}

The inhibitory activities of $25 \mathrm{LAB}$ isolates was confirmed with the spot-on-lawn assay as described by Schillinger and Lücke [15], Lewus et al. [13]), and Van Reenen et al. [16]. Overnight cultures of LAB isolates to be tested were spotted $\left(5 \mathrm{\mu l}\right.$ ) onto the surface of MRS agar medium (4 spots in each plate) and incubated anaerobically at $37^{\circ} \mathrm{C}$ for $24 \mathrm{~h}$ to allow colonies to develop. Anaerobic conditions were used to minimize the formation of hydrogen peroxide and acetic acid. Each plate was overlaid with $7 \mathrm{ml}$ of soft agar $(0.75 \%)$ seeded with $0.5 \mathrm{ml}$ of overnight cultures of the indicator organisms. The plates were incubated at $37^{\circ} \mathrm{C}$ for $24 \mathrm{~h}$ and clear zones around the spots were observed. The antagonism was detected by the formation of a growth inhibition halo of the indicator microorganisms around bacteriocins test isolates. Isolates producing clear inhibition zones were selected and used for further testing by the agar well diffusion method.

\subsection{Testing by the well-diffusion method}

Only 15 strains showing promise of antagonistic activity against the indicator bacteria were further used for confirmation of their activity by the well-diffusion method [14].In this method, cell-free supernatants of the test isolates were used to inhibit growth of the indicator bacteria.

\subsection{Preparation of the cell-free supernatants}

For the detection of antibacterial activity of each isolate, the method of Çadirci and Çitak [17 ] was followed, in which a 24-hour old culture of the isolate was used to inoculate MRS broth $(2 \%)$ in test tubes. The inoculated tubes were incubated at $30^{\circ} \mathrm{C}$ for 72 hours without shaking. At the end of the incubation period, the cells were separated by centrifugation at $6000 \mathrm{rpm}$ for 25 minutes in a centrifuge (Zentrifugen / Hettich D-78532 Tuttlingen, Germany). The pH of the culture was adjusted to $\mathrm{pH} 5.5$ with sterile $7.0 \mathrm{M} \mathrm{NaOH}$ and cells were then desorbed at $\mathrm{pH}$ 2-2.5 in the presence of sterile $0.1 \mathrm{~N} \mathrm{NaCl}[18 ; 19]$. The cell-free supernatants were carefully decanted, cellulose acetate filter-sterilized (pore size $0.45 \mu \mathrm{m}$, Sartorius Stedium Biotech GmbH37070 Geettingen, Germany) and were kept at 4을 for use in the determination of their antagonistic activities against the 6 indicators bacteria, and for their characterization.

\subsection{Conducting the well-diffusion test}

Molten Nutrient Agar (N.A.) medium $\left(48^{\circ} \mathrm{C}\right)$ was first seeded with washed cells of the indicator bacteria, and the inoculated medium was immediately poured into sterile Petri dishes. After solidification, the medium was allowed to dry for at least 30 minutes at room temperature. Four wells of uniform diameter (about $5 \mathrm{~mm}$ ) were aseptically bored in the agar using a sterile Pasteur pipette. Fifty $\mu$ l of each of the 15 cell-free supernatants of each test isolate (72 hoursold) were dispensed into three wells, while sterile MRS agar medium was poured into the fourth well to serve as a control treatment. Plates were left to stand for at least five hours at room temperature to allow diffusion of the cell-free extracts. The plates were then incubated inverted at $30^{\circ} \mathrm{C}$ for 24 hours. At the end of the incubation period, diameters of the resulting inhibition zones, if any, were measured and the results recorded in $\mathrm{cm}$. 


\section{Results and discussion}

\subsection{Screening for antagonistic activity using spot-on-lawn method}

A preliminary screening of the possible antagonistic activity of the isolates against 6 indicator bacteria, three of which were reference strains (Staphylococcus aureus ATCC 29213, Salmonella typhi ATCC 14023 and E. coli ATCC 25922), in addition to three indicator strains from the same genera isolated from the processed meat samples. Screening was conducted by the spot-on-lawn method [13]. Table 1 Shows that 15 of the isolates produced inhibition zones against all or some of the indicator strains, 12 of which showed antagonistic activity against all six indicator bacteria. Six of these were obtained from burger, three samples from frankfurter, two from pastrami, two from sausage and two from infant faeces.

Most of the burger isolates showed inhibitory activity against all indicators except isolate B41 which failed to inhibit Staphylococcus aureus, while the frankfurter isolate F3 failed to inhabit E. coli ATCC 25922. The pastrami isolate P2 was active only against E. coli ATCC 25922 and Salmonella typhi ATCC 14023 and failed to inhibit the remaining indicators. However, isolates obtained from sausage and infant faeces showed inhibition activity against all indicators.

This study was started by the isolation of a large number of promising bacteriocin-producing bacteria from a wide variety of samples (meat products samples and infant faeces). Conventry et al. [20] reported that the detection rate of bac+ strains from LAB isolates can be as low as $0.2 \%$ and therefore needs a large number of isolates from food sources. A total of about 25 colonies isolated from these samples were examined for detection of antibacterial activity against a set of 6 indicators. Activity against Gram-negative strains by Gram-positive bacteriocin producers has rarely been reported $[21 ; 22 ; 23 ; 24]$.

\subsection{Screening by the well-diffusion method}

More stringent screening of the 15 isolates was carried out by the well-diffusion method [14], using cell-free supernatants prepared from the test isolates. Supernatants were prepared from each strain after incubation at $30^{\circ} \mathrm{C}$ for 72 hours in MRS broth.

Table 1 Bacteriocin activity (measured as diameter of inhibition zones in $\mathrm{cm}$ ) against six target organisms by the spot on-lawn assay

\begin{tabular}{|c|c|c|c|c|c|c|c|}
\hline \multicolumn{8}{|c|}{ Indicator organisms/ DIZ } \\
\hline $\begin{array}{l}\text { Isolate } \\
\text { code }\end{array}$ & Source & $\begin{array}{c}\text { Salmonella } \\
\text { typhi } \\
\text { ATCC14023 }\end{array}$ & $\begin{array}{c}\text { Salmonella } \\
\text { typhi local }\end{array}$ & $\begin{array}{c}\text { Escherichia } \\
\text { coli } \\
\text { ATCC25922 }\end{array}$ & $\begin{array}{l}\text { Escherichia } \\
\text { coli local }\end{array}$ & $\begin{array}{c}\text { Staphylococcus } \\
\text { aureus } \\
\text { ATCC29213 }\end{array}$ & $\begin{array}{l}\text { Staphylococcus } \\
\text { aureus local }\end{array}$ \\
\hline $\mathrm{B} 2{ }_{1}$ & Factory2 & 1.8 & 2.0 & 1.5 & 2.0 & 2.0 & 1.5 \\
\hline $\mathrm{B} 2_{2}$ & Factory2 & 2.3 & 4.0 & 3.6 & 2.6 & 3.0 & 3.5 \\
\hline B3 ${ }_{1}$ & Factory3 & 3.0 & 3.0 & 2.7 & 2.7 & 2.3 & 3.0 \\
\hline $\mathrm{B} 3{ }_{4}$ & Factory3 & 4.0 & 3.2 & 2.4 & 2.0 & 2.2 & 3.5 \\
\hline $\mathrm{B} 4{ }_{3}$ & Factory 4 & 3.5 & 3.3 & 2.7 & 2.2 & 2.5 & 4.0 \\
\hline $\mathrm{B} 4_{1}$ & Factory 4 & 3.8 & 2.2 & 3.6 & 1.8 & 0.0 & 0.0 \\
\hline $\mathrm{F} 1$ & Factory1 & 2.0 & 4.2 & 2.3 & 3.0 & 2.5 & 1.2 \\
\hline F2 & Factory2 & 1.2 & 4.0 & 2.8 & 1.8 & 3.0 & 1.2 \\
\hline F3 & Factory3 & 2.0 & 2.5 & 0.0 & 1.2 & 2.5 & 2.7 \\
\hline $\mathrm{P} 1$ & Factory1 & 2.4 & 3.7 & 2.2 & 2.0 & 3.4 & 2.5 \\
\hline $\mathrm{P} 2$ & Factory2 & 2.0 & 0.0 & 1.8 & 0.0 & 0.0 & 0.0 \\
\hline S1 & Factory1 & 2.0 & 1.5 & 1.0 & 2.0 & 3.0 & 2.5 \\
\hline S2 & Factory2 & 2.0 & 2.3 & 2.0 & 1.5 & 2.5 & 2.5 \\
\hline
\end{tabular}




\begin{tabular}{|c|c|c|c|c|c|c|c|}
\hline Bf1 & $\begin{array}{c}\text { Baby } \\
\text { faeces }\end{array}$ & 2.8 & 2.0 & 1.5 & 2.5 & 2.2 & 2.0 \\
\hline Bf2 & $\begin{array}{c}\text { Baby } \\
\text { faeces }\end{array}$ & 3.0 & 2.6 & 2.7 & 3.0 & 2.5 & 2.0 \\
\hline
\end{tabular}

DIZ: Diameter of Inhibition Zones. F1, F2, F3 =Frankfurter.

$\mathrm{B} 4_{1}, \mathrm{~B} 2_{1}, \mathrm{~B} 22_{2}, \mathrm{~B} 3_{1}, \mathrm{~B} 3_{4}, \mathrm{~B} 4_{3}=$ Burger. P1, P2, P3 = Pastrami; S1, S2 = Sausage. Bf1, Bf2 = Baby faeces

Table 2 Bacteriocin activity measurement (Inhibition zone diameters, $\mathrm{cm}$ ) produced by supernatants from 5 isolates against six indicator bacteria by the agar well diffusion method

\begin{tabular}{|c|c|c|c|c|c|c|c|}
\hline \multicolumn{8}{|c|}{ Indicator organisms (IZD) } \\
\hline $\begin{array}{l}\text { Isolate } \\
\text { code }\end{array}$ & Source & $\begin{array}{c}\text { Salmonella } \\
\text { typhi } \\
\text { ATCC14023 }\end{array}$ & $\begin{array}{c}\text { Salmonella } \\
\text { typhi local }\end{array}$ & $\begin{array}{c}\text { Staphylococcus } \\
\text { aureus } \\
\text { ATCC29213 }\end{array}$ & $\begin{array}{l}\text { Staphylococcus } \\
\text { aureus local }\end{array}$ & $\begin{array}{c}\text { Escherichia } \\
\text { coli } \\
\text { ATCC25922 }\end{array}$ & $\begin{array}{c}\text { Escherichia } \\
\text { coli local }\end{array}$ \\
\hline $\mathrm{B} 2_{2}$ & Burger & 1.7 & 1.5 & 1.4 & 1.3 & 0.0 & 0.0 \\
\hline S1 & Sausage & 2.0 & 1.3 & 1.2 & 2.5 & 1.2 & 1.3 \\
\hline $\mathrm{S} 2$ & Sausage & 1.8 & 1.5 & 1.0 & 2.4 & 1.0 & 1.3 \\
\hline Bf1 & $\begin{array}{l}\text { Baby } \\
\text { faeces }\end{array}$ & 1.9 & 1.5 & 1.4 & 2.0 & 1.7 & 1.1 \\
\hline Bf2 & $\begin{array}{l}\text { Baby } \\
\text { faeces }\end{array}$ & 2.3 & 2.0 & 1.5 & 2.7 & 1.5 & 1.4 \\
\hline
\end{tabular}

IDZ: Inhibition Zone of Diameter.

Table 2 shows diameters of inhibition zones produced by the test isolates against the indicator bacterium. Only 5 isolates produced inhibition zones, 4 isolates of which produced inhibition against all indicators, while the isolate from Burger (B22) failed to show any inhibition against E. coli. The most predominant inhibition zones were produced by the isolates ( $\mathrm{S} 1, \mathrm{~S} 2, \mathrm{Bf} 1$ and $\mathrm{Bf} 2$ ). It is also to be noted that isolate Bf2 which was obtained from baby faeces produced prominent inhibition zones against all indicators in comparison with the other isolates except Escherichia coli ATCC 25922.

Only 5 isolates produced antibacterial activity in the cell-free supernatant by using the well-diffusion assay, 4 isolates produced inhibition against all indicators except isolate $\left(B 2_{2}\right)$ from burger, which failed to show any inhibition against E. coli. These negative results could show that bacteriocin production is not highly conserved in these strains. Some of the bacteriocins are plasmid-mediated proteins [25], so one should consider the possibility that some cultures could have lost their plasmids after consecutive transfers during the purification. Lewus et al. [13] found that only a few of the strains that tested positive using the spot on-lawn method gave positive results in the well diffusion assay. They considered that allowing some time for the bacteriocins to diffuse into the agar prior to incubation, or increasing the well size, so that more sample could be applied, might increase the sensitivity of the assay. Also Schillinger and Lücke [15] observed similar findings on checking Lactobacillus sake strains that were positive in the agar spot test and negative in the well diffusion assay.

The results indicate, the diameters of the inhibition zones varied, and ranged between 1.1 and $2.7 \mathrm{~cm}$. This revealed that the LAB inhibited all the pathogenic bacteria tested according to [15] who mentioned that inhibition was scored positive if the width of the clear zone around the colonies of the producer strain was $0.5 \mathrm{~mm}$ or larger. Local Staph. aureus, as a target organism, demonstrated the highest detection rate among indicator bacteria that ranged from 1.3 to $2.7 \mathrm{~cm}$ in diameter in isolate B2 2 to bf2, respectively. These findings are in agreement with those obtained by Bromberg et al. [26] who determined the production bacteriocin- like substances by some lactic acid bacteria isolated from meat and meat products active against Staphylococcus aureus. The most prominent inhibition zones were produced by the isolates (S1, $\mathrm{S} 2, \mathrm{Bf} 1$ and Bf2). It is also to be noted that isolate (Bf2), which was obtained from baby faeces produced prominent inhibition zones against all indicators in comparison with the other isolates, except in E. coli ATCC 25922. 


\section{Conclusion}

- The produced bacteriocins showed a wide spectrum of antimicrobial activity against spoilage and pathogenic indicator organisms.

- Only a few of the strains tested positive using the spot on-lawn method, and gave positive results in the well diffusion assay. This indicates the need for some time for the bacteriocins to diffuse into the agar prior to incubation, or increasing the well size so that more sample could be applied, which might increase the sensitivity of the assay.

\section{Compliance with ethical standards}

\section{Acknowledgments}

The authors thanks the members of the Department of Agricultural Biotechnology, Faculty of Agriculture, University of Khartoum, and Biology Department, Faculty of Education, Alzaiem Alazhari University for their assistance during the study.

\section{Disclosure of conflict of interest}

The authors have declared that no competing interests exist.

\section{References}

[1] Jimenez-Colmenero F, Caraballo S, Cofreds S. Healthier meat and meat products: their role as functional foods. Meat Science. 2001; 59: 5-13.

[2] Shahrasebi H, Naseri A. Nutrition value and practical methods of chemical and hygienic control of some Iran meat products. Publication of ISBA of Iran. 1985.

[3] Caplice E, Fitzgerald GF. Food fermentations: role of microorganisms in food production and preservation. International Journal of Food Microbiology. 1999; 50(1-2): 131-149.

[4] Carr FJ, Chill D, Maida N. The lactic acid bacteria. A literature survey. Critical Reviews in Microbiology. 2002; 28 : 281-370.

[5] De Vuyst L, Vandamme EJ. Antimicrobial potential of lactic acid bacteria. In: Bacteriocins of Lactic Acid Bacteria. Microbiology, Genetics and Applications. Blackie Academic and Professional, London. 1994; 91-142.

[6] Klaenhammer TR, Fremaux C, Hechard Y, activité antimicrobienne des bactéries lactiques. In-Bactéries Latiques, H. De Roissart and F. M. Luquet, Lorica. 1994.

[7] Moreno MR, Sarantinopoulos P, Tsakalidon E, De Vuyst L. The role and application of enterococcin in food and health. International Journal of Food Microbiology. 2006; 106: 1-24.

[8] O'Sullivan L, Ross RP, Hill C, Potential of bacteriocin-producing lactic acid bacteria for improvements in food safety and quality. Biochimie journal. 2002; 84: 593-604.

[9] Sneath PHA, Mair NS, Sharp ME, Holt JG, Bergy's Manual of Systematic Bacteriology. 1986; 2.

[10] Barrow GI, Feltham RKA. (Editors). Cowan and Steel's Manual for the Identification of Medical Bacteria, $3^{\text {rd }}$ edition. Cambridge University Press, England. 1993.

[11] Harrigan WE, Laboratory Methods in Food and Dairy Microbiology. Academic press. USA. 1998.

[12] Salminen S, Wright AV, Ouwehand A, Lactic Acid Bacteria. Microbiology and Functional Aspects. $3^{\text {rd }}$ edition. 2004; Marcel Dekker, Inc. New York. Basel.

[13] Lewus CB,Kaiser A, Montville TJ. Inhibition of food-borne pathogens by bacteriocins from lactic acid bacteria isolated from meat. Applied and Environmental microbiology. 1991; 57(6):1683-1688.

[14] Barefoot SF, Klaenhammer TR. Detection and activity of lactopcin B, a bacteriocin produced by lactobacillus. Applied and Environmental Microbiology.1983; 45:1808-1815.

[15] Schillinger, V and lucke, FK. Antimicrobial activity of Lactobacillus sake isolated from meat. Applied and Environmental Microbiology,1989; 55(8):1901-1906. 
[16] Van Reenen CA, Dicks LMT, Chikindas ML, Isolation, purification and partial characterization of plantaricin 423, a bacteriocin produced by Lactobacillus plantarum. Journal of Applied Microbiology. 1998; 84: 1131-1137.

[17] Cadirci BH, Citak S. A comparison of two methods used for measuring antagonistic activity of lactic acid bacteria. Pakistan Journal Nutrition. 2005; 4: 237-241.

[18] Yang R, Johnson MC, Ray B. Novel Methods to extract large amount of bacteriocin from lactic acid bacteria. Applied and Environmental Microbiology. 1992; 58: 3355-3359.

[19] Vera Pingitore E, Salvucc E , Sesma F, Nader-Macias ME, Different for purification of antimicrobial peptide from Lactic Acid Bacteria (LAB).Communicating Current Research and Educational Tropics and Trends in Applied Microbiology. 2007; Mendez-Vilas (Ed). 557-568.

[20] Conventry MJ, Gordon JB, Wilcock A, Harmark K, Davidson BE, Hickey MW, Hillier AJ, Wan J. Detection of bacteriocin of LAB isolated from food and comparison with pediocin and nisin. Journal of Applied Microbiology. 1997; 83: 248-258.

[21] Blackburn P, Polak J, Gusik SA, Rubing SD. Nisin composition for use as enhanced broad range bactericides. International Patent Application publication WO. 1989; 89: 112-399.

[22] Stevens KA, Sheldon BW, Klapes NA, Klaenhammer TR. Nisin treatment for inactivation of Salmonella species and other Gram negative bacteria. Applied and Environmental Microbiology. 1991; 57(12): 3613-3615.

[23] Kalchayand N, Hanilin MB, Ray B. Sublethal injury makes Gram-negative and resistant Gram- positive bacteria sensitive to the bacteriocin, pediocin AcH and nisin. Letters in Applied Microbiology. 1992; 14: 239-243.

[24] Arihara K, Ogihara S, Mukai T, Itoh, M, and Kondo Y, Salivacin 140, a novel bacteriocin from Lactobacillus salivarius subsp. salicinius T140 active against pathogenic bacteria. Letters in Applied Microbiology. 1996; 22: 420-424.

[25] Tagg JR, Dajani AS, Wannamaker LW. Bacteriocins of gram positive bacteria. Bacteriological Reviews. 1976; 40: 722-756.

[26] Bromberg R, Moreno I, Zaganini CL, Delboni RR, de Olivera J, Isolation of bacteriocin-producing Lactic acid bacteria from meat and meat products and its spectrum of inhibitory activity. Brazilian Journal of Microbiology. 2004; 35(1-2): 137-144. 